\title{
On being a discontinuous person: Ontological insecurity, the wounded storyteller and time in Daniel Keyes's Flowers for Algernon
}

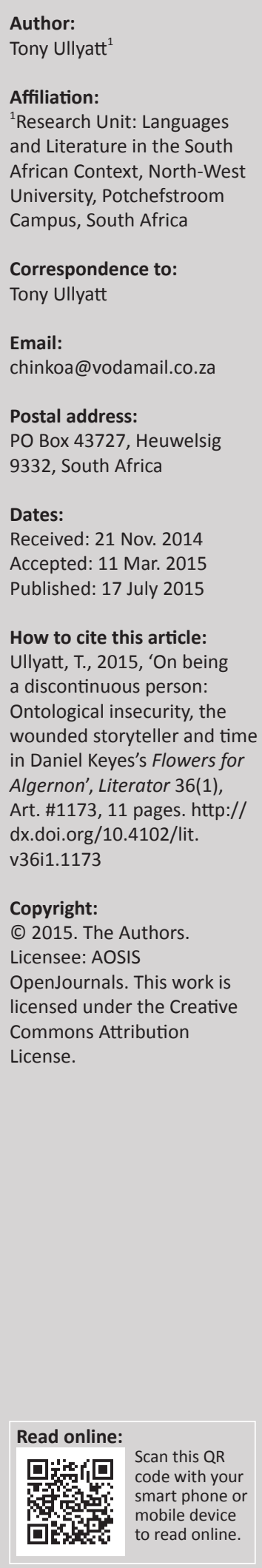

This article explores ontological security and insecurity in Daniel Keyes's novel, Flowers for Algernon. It opens with a very brief overview of the 1960s counter-culture to contextualise not only Keyes's novel but also Laing's theories of ontological (in)security. After a discussion of Laing's concept of ontological security and insecurity, the focus shifts to Arthur W. Frank's notions of the wounded storyteller and how Charlie Gordon's entry into the medical world constitutes a colonisation of the body that brings with it a deepening sense of ontological insecurity. In entering the world of medical research, Charlie becomes the wounded storyteller, offering a first-person account of his experiences during the experiment and its aftermath. As the initial success of the surgery deteriorates steadily into failure, with the protagonist's intelligence returning steadily to its pre-operation level, the question of time and how he can make the best use of it to record the experiment becomes paramount. The final section of the article centres on the growing link between the surgery's failure and how it increases the protagonist's ontological insecurity. He uses the diminishing amount of time available to him in search of understanding the fuller implications of the experiment. Eventually, he reverts to his initial rudimentary ontological security when he finds himself with the same intellectual level, as prior to the experiment.

Om 'n onderbroke persoon te wees: Ontologiese onsekerheid en tyd in Daniel Keyes se Flowers for Algernon. Hierdie artikel ondersoek ontologiese sekerheid en onsekerheid in Daniel Keyes se roman, Flowers for Algernon. Dit begin met 'n kort oorsig oor die kontrakultuur van die 1960's ten einde sowel Keyes se roman as Laing se teorieë oor ontologiese (on) sekerheid te kontekstualiseer. $\mathrm{Na}$ 'n bespreking van Laing se konsep van ontologiese sekerheid en onsekerheid word die fokus verskuif na Arthur W. Frank se begrip van die verwonde verteller en hoe Charlie Gordon se toetrede tot die mediese wêreld 'n kolonisering van die liggaam voorstel wat tegelykertyd 'n dieper wordende gevoel van ontologiese onsekerheid meebring. Wanneer Charlie die wêreld van mediese navorsing betree, word hy 'n verwonde verteller en gee hy in die eerste persoon rekenskap van sy ondervinding gedurende en na die eksperiment. Terwyl die aanvanklike sukses van die operasie geleidelik tot mislukking vervaag, met die hoofkarakter se intelligensie wat dan ook geleidelik tot die pre-operasievlak daal, word die kwessie van tyd en hoe Charlie dit die beste kan opteken, van oorheersende belang. Die artikel se laaste afdeling fokus op die groterwordende skakel tussen die mislukte operasie en die verhoging van die hoofkarakter se ontologiese onsekerheid. Hy gebruik die beperkte tyd wat tot sy beskikking is om die implikasies van die eksperiment breedvoeriger te verstaan. Uiteindelik keer hy terug na sy rudimentêre ontologiese sekerheid wanneer hy homself weer op dieselfde intellektuele vlak bevind as voor die eksperiment.

\section{The 1960s counter-culture: A brief glimpse}

For most of us, counter-culture conjures up images of a particular chapter of the American story. We associate it with the Beat movement and the sixties era, and with the infamous Summer of Love, The Free Speech movement, militant Yippies, and psychedelic drugs come to mind as well. All were symptomatic that the cultural mainstream was heading in the wrong direction. (Watts 1997:vii; italics original)

Of the countless new theories, philosophies and other socio-cultural manifestations which the 1960s counter-culture engendered, the particular concern here will be with those relating to mental illness and its treatment, and the criticisms of mainstream ideas by counter-culture authors. The broad background of the 1960s and, more specifically, writings on mental illness is singularly relevant to the subject of this article because it was during that era that Daniel Keyes wrote Flowers for Algernon. 
Parenthetically, the sixties was also the time when Ken Kesey produced One flew over the cuckoo's nest, its protagonist a petty criminal recidivist who is finally given shock treatment to stifle his refusal to conform to the mental hospital's authoritarian regime.

During the 1960s, several seminal works on mental illness and its prevailing methods of treatment as well as their socio-political implications were written. Ideas drawn from these works serve as the theoretical foundations on which the present exploration of Keyes's novel will be based. For example, Laing's theories of ontological security and interpersonal perception were promulgated in 1960 and 1966 respectively. In 1961, the sociologist, Ervin Goffman, put forward his concept of the 'total institution' to describe, amongst others, monasteries, hospitals, army camps, prisons and mental institutions. Two years later, Goffman's book on the social phenomenon of stigmatisation appeared whilst David Cooper coined the term 'anti-psychiatry' in 1967. Although his work is not used here, Thomas Szasz proposed his provocative myth of mental illness, also in 1961.

These writers were deeply concerned about long-established diagnostic and treatment practices in mainstream psychology and psychiatry as well as the socio-political norms they embodied. Writing in 1964, Laing (1970) explains one of the primary issues:

Psychiatry has been particularly concerned with individual experiences and behaviour regarded in our society as 'abnormal'

In an effort to bring psychiatry into line with neurology and medicine in general, attempts have been made to categorise such experience and behaviour into 'symptoms' and 'signs' of supposedly pathological syndromes or illnesses (p. 16)

These approaches to mental illness were rooted in the socalled medical model, what Arthur W. Frank (1997:75) would later call 'the restitution narrative'. Simply put, the medical process follows this generic pattern: The patient presents with symptoms of illness, is diagnosed, is hospitalised (when necessary) and undergoes a series of treatments based on the diagnosis before being discharged when health has been restored. The problem with this model arises when it is applied to mental conditions because not all of them have biological origins and therefore are not susceptible to pharmacological treatments. In pursuit of cures for the symptoms of mental illness, destructive, invasive treatments such as electroconvulsive or shock therapy (ECT), insulin shock therapy and surgical procedures such as lobotomies were used. Involuntary incarceration in highly-regimented mental institutions also occurred. The anti-psychiatry movement construed these procedures as deliberately oppressive and violent and thus useful in controlling 'abnormal' patients. As David Cooper (1967:14) summed it up as follows: 'At the heart of the problem is violence'. A little later, he states: '.. in fact, violence in psychiatry is preeminently the violence of psychiatry.'
It was argued that these established treatments of mental 'illnesses' also had - and often hid - a more insidious political agenda. According to David Cooper (1971:11), one of the most politicised proponents of anti-psychiatry, the purpose behind these medical procedures was to produce '... the well-conditioned, endlessly obedient citizen'. Individuals are generally shaped into socially permissible behaviour from their earliest days as Bohm (2004) asserts:

... generally speaking, what we learn as children, from parents, teachers, friends, and society in general is to have a conformist, imitative, mechanical state of mind that does not present the disturbing danger of 'upsetting the apple cart'. (p. 20)

Bentall (2004) observes in the following words:

By the middle of the twentieth century, it was becoming obvious to many psychiatrists that the achievement of a consensus about the main features of each psychiatric disorder would not be enough to ensure that diagnoses were reliable, let alone scientifically reliable. (p. 47)

On their part, Long and Zietkiewicz (2002) report the following:

... data from virtually every continent are suggesting that culture is not simply incidental to mental health and therapy. Rather, it is a basic variable that interacts with biological, psychological and environmental variables in determining the cause, manifestation and treatment of the entire spectrum of mental disorders. (p. 152)

The links between psychiatry and politics became so interwoven that, by the time Peter Sedgwick (1982) came to survey the influential anti-psychiatry writers of the 1960s, his book bore the title Psycho politics and the sub-title Laing, Foucault, Goffman, Szasz and the future of mass psychiatry.

Psychiatry and its modus operandi within hospitals and mental institutions were also considered instruments of oppression through the exploitation of the unequal power relationship between doctors and institutional officials, on the one hand, and patients, on the other. Such views have continued to the present day. It is against the norms of accepted and acceptable (that is, conformist) social conduct that notions of, and judgements about, abnormality, madness and criminality have been established, assessed and treated (or punished), thus engendering a societal ethos of command and control. Indeed, as late as 2002, Derek Hook (2002:5-6) points out that '... the abnormal is defined by the normal' (italics original). Nonetheless, as Mark Watts (1997:xi) observes, the counter-culture's '... message will not be going away any time soon'.

\section{Ontological (in)security}

Laing (1990:39) focuses on the issue of ontological insecurity in the third chapter of his seminal work, The divided self. He offers this description (in the male-gender biased language of the time) of an ontologically secure person:

A man may have a sense of his presence in the world as a real, alive, whole, and, in a temporal sense, a continuous person. As such, he can live out into the world and meet others: a world 
and others experienced as equally real, alive, whole, and continuous. (p. 39)

Clearly, the person Laing describes is mentally stable and mature with a sense of order and continuity about the events of his or her life. Such stability relies on the individual's capacity for giving life meaning. He or she avoids chaos because of their sense of wholeness and thus has the ability to avoid or cope with anxieties that might be caused by disorder and discontinuity.

Ontological security presumes mental stability to manage the vicissitudes of human existence, an accurate perception of reality and the ability to deal with their consequences. It also presumes stable perceptions of the self as well as similar presumptions about other individuals' understanding of their individual selves and of others. Laing (1990) continues as follows:

Such a basically ontologically secure person will encounter all the hazards of life, social, ethical, spiritual, biological, from a centrally firm sense of his own and other people's reality and identity (p. 39)

Singularly important in this extract and the previous one is the idea that ontological security does not happen in isolation; it is dialogic, operating at all levels of social interaction. In Interpersonal perception, which Laing coauthored with Herbert Phillipson and A Russell Lee, they explain this point:

Self-identity (my view of myself) and meta-identity (my view of your view of me) are theoretical constructs, not concrete realities. In concreto, rather than in abstracto, self-identity (' $\mathrm{I}$ ' looking at 'me') is constituted not only by our looking at ourselves, but also by our looking at others looking at us and our reconstitution and alteration of these views of the others about us. At this more complex, more concrete level, self-identity is a synthesis of my looking at me with my view of others' views of me. These views by others of me need not be passively accepted, but they cannot be ignored in my development of a sense of who I am. For even if a view by another of me is rejected it still becomes incorporated in its rejected form as part of my self-identity. (Laing, Phillipson \& Lee 1966:4)

The ways in which others see a person is a question of interpretation by the individual concerned. The opinions or attitudes of others may even be rejected. Nonetheless, they will be acted upon, albeit negatively.

Quite evidently, the development of self-identity and its concomitant ontological security is inseparable from interpersonal interaction. For instance, Charlie's mother's violent behaviour towards him during his childhood and adolescence accounts for his nightmarish recollections of those times and its contribution to his ontological insecurity, especially regarding relationships with women. He is '... Charlie, the little boy who's afraid of women because of the things his mother did to him' (Keyes 1989:42). ${ }^{1}$

1.Subsequent references to Flowers for Algernon will contain only page numbers.
Later in The divided self, Laing (1990) expands upon the numerous elements involved in an individual's ontological security:

The individual, then, may experience his own being as real, alive, whole; as differentiated from the rest of the world in ordinary circumstances so clearly that his identity and autonomy are never in question; as a continuum in time; as having an inner consistency, substantiality, genuineness, and worth; as spatially co-extensive with the body; and, usually, as having begun in or around birth and liable to extinction with death. He thus has a firm core of ontological security. (pp. 41-42)

Of course, we need to remember that Laing's discussion is based on assumptions of normal mental ability. However, Charlie's case raises some perplexing issues regarding ontological security. One might question what ontological security means to a person with Charlie's below-average mental abilities. Is Charlie able to perceive himself as '... differentiated from the rest of the world in ordinary circumstances so clearly that his identity and autonomy are never in question'? (p. 41).

Because he has little sense of others, he fails to perceive and interpret their negative attitudes in any way other than affirmatively. Consequently, Charlie perceives himself as 'basically ontologically secure' (Laing 1990:39) in his limited way. In his eighth progress report, Charlie describes going back to work at Donner's after the surgery:

We had a lot of fun at the bakery today. Joe Carp said hey look where Charlie had his operashun what did they do Charlie put some brains in. I was going to tell him about me getting smart but I remembered Prof Nemur said no. Then Frank Reilly said what did you do Charlie open a door the hard way. That made me laff. Their my frends and they really like me. (p. 16)

Whilst his colleagues at Donner's Bakery taunt and ridicule him, from within his own limited awareness, Charlie perceives this as good-natured banter and even friendship. His blithe sense of ontological security is founded upon his inability to grasp the real 'attitudes, opinions, needs' of the others towards him. Subsequently in the same report, Charlie writes: 'I can't wait to be smart like my best frends Joe Carp and Frank Reilly' (p. 22). At this stage, these co-workers are seen as the yardstick by which intelligence is measured.

When Charlie is chosen for the experiment, his ontological naivety, together with his desire to be 'smart' (p. 22), deludes him to the extent that he does not entertain the possibility of failure. Of course, it is precisely this point at which Charlie's rudimentary ontological security begins to be undermined. In presuming that the researchers also wish Charlie to become 'smart', he fails to grasp important aspects of their ontological security. For instance, as proponents of the medical model for treating illness, Professor Nemur and Doctor Strauss risk Charlie's brain surgery because their purpose is to raise him to society's prevailing norms of normality through the success of the surgery, to say nothing of the professional enhancement that would accompany such an achievement. In their scientific world, whether successful 
or not, the experiment will provide useful knowledge. That is beyond Charlie's comprehension.

Charlie records their decision in his fifth 'progris report' (pp. 7-8). Nemur says: 'We will use Charlie. But we've got to make him understand that a lot of things can go wrong with the experiment' (p. 8). Of course, 'making him understand' is not readily accomplished, not only because of Charlie's current intelligence level but also because of his inability to decipher their words of caution or to visualise the possibility or consequences of failure.

Looking back at these very early stages of the experiment, he tells Nemur, 'I didn't understand at the time what you meant by it. But that's beside the point now because I'm aware of it now' (p. 153). Although the experiment might have given him super-intelligence (albeit temporarily), it is while at that superior level of intelligence that he is able to comprehend fully the extent of the ontological insecurity that the two scientists have brought into his day-to-day existence. This insecurity is intensified by what happens to Algernon, the laboratory mouse who has also undergone the same operation.

Professor Nemur and Dr Strauss have what Laing (1990, p. 42) calls '... a firm core of ontological security'. In their own professional lives, they remain secure in acknowledging the risks involved in the experiment. In Laing's (p. 39) words, they have '... a sense of integral selfhood and personal identity, of the substantiality of natural processes, of the substantiality of others', a sense which makes it difficult for them to place themselves in Charlie's position. Instead, they are inclined to handle him in a way reminiscent of a laboratory animal.

What the scientists also do not recognise is that their intervention will undermine Charlie's ontological certainties. As the experiment continues, he comes to question his own identity through his interaction with others, especially Nemur, Strauss and Burt, their PhD student and assistant. This questioning or doubting process continues through his own later research findings: 'Who and what am I now?' (p. 108). His ontological insecurity mounts as he discovers that they are '... men who don't know all the answers' (p. 108).

In Progress Report 11, Charlie recounts the events of an evening out '... to a movie and then to dinner ...' with Alice Kinnian. The evening has some awkward, embarrassing moments. Charlie is becoming all too painfully aware that his intellectual development has not been matched by a parallel emotional growth. Afterwards, on the way home in a taxi, Alice apologises: 'I upset you by talking about it the experiment]. I made you feel self-conscious' (p. 57).

Laing (1990:106) explains the two implications of selfconsciousness: '... an awareness of oneself by oneself, and an awareness of oneself as an object of someone else's observations' (italics original). One recalls here the interpersonal, dialogic nature of ontological security mentioned earlier and notes the part it plays in an individual's sense of ontological security or insecurity. Charlie finds it difficult to process a comment like Alice's without it having a further negative bearing on his insecurity.

Although Charlie is the protagonist of the novel, Algernon the laboratory mouse plays an equally significant role as Charlie's experimental harbinger. Despite the fact that the surgery had been tried on a number of mice, '... none of the others achieved so high a level of intelligence nor maintained it for so long as Algernon' (p. 111-112). Burt's comments at the Chicago Convention are cause for optimism as interim feedback on the experiment thus far, but they are scientifically unreliable as predictors of the eventual outcomes of the experiment. However, on the basis of these optimistic but provisional findings, Nemur makes his decision to use Charlie.

It is against Algernon's performance in running mazes that Charlie first pits his wits and experiences both a sense of failure and an initial brush with ontological insecurity: 'I dint know mice were so smart' (p. 7). Earlier, when asked to take the Rorschach Test as another part of the experiment's early evaluation phase, Charlie 'couldn't see no picturs' (p. 2) and presumes 'I don't think I passd the raw shok test' (p. 3). Previously, at the 'beekman collidge center for retarted adults', Alice Kinnian had tested only his 'riting and reeding' (p. 3).

Once Nemur has decided to use Charlie - there is a potent ambiguity in the word 'use' - Charlie's delight obscures the scientist's various caveats. Even though he records the scientists' concerns, he is unable to comprehend their implications until much later:

We are sure theres no fisical danger for you but there are other things we cant tell until we try. I want you to understand this might fale and then nothing woud happen at all. Or it mite even sucseed temperary and leave you werse off than you are now ... If that happins we will have to send you bak to the Warren state home to live. (p. 8)

From Charlie's point of view, things can only get better.

The idea of 'a continuous person' who experiences both the 'world and others ... as equally real, alive, whole, and continuous' (Laing 1990:39) is disrupted when illness occurs. As Frank (1997, p. 56) puts it: 'In the beginning is an interruption.' There are several consequences to this interruption, the first of which is that the individual is rendered 'discontinuous' (Frank 1997:109), thus losing what Laing refers to as 'a firm core of ontological security' (Frank 1997:42) engendered by one's sense of continuity.

Charlie's rapid intellectual development has a dramatic impact on 'his identity and autonomy'. As the experiment continues, he comes to question his own identity through his interaction with others, especially the two scientists and Burt, as well as through his own research findings: 'Who and what am I now?' (p. 108). Charlie finds part of the answer to that question in observing Algernon's own post-operative behaviour. 
Charlie's original retardation yields to the restitution model's desired outcome: normality. However, his intellectual growth continues beyond the scientists' control and beyond their expectations until Charlie becomes 'abnormal' again, albeit in the obverse way. He becomes a polyglot (pp. 105106), a composer (p. 149) and a researcher on 'the calculus of intelligence' (p. 166). These extraordinary accomplishments bring a certain measure of ontological security with them. Yet the absence of parallel emotional development contributes a further dimension to the societal abnormality of his phenomenal IQ: 'I know now there's one thing you've all overlooked: intelligence and education that hasn't been tempered by human affection isn't worth a damn' (p. 175).

He remains emotionally underdeveloped even late in the novel. Speaking to Alice Kinnian, he says:

All these months while I've been growing up intellectually, I've still had the emotional wiring of the childlike Charlie. And every time I came close to you, or thought about making love to you, there was a short circuit. (p. 142)

Charlie explains the cause of this 'short circuit' to Alice Kinnian by tracing it back to his mother's behaviour during his early years.

The consequences of this discrepancy between intellect and emotion introduce another factor reinforcing Charlie's ontological insecurity: 'I realize that emotional problems can't be solved as intellectual problems are ... Somehow I've become separated emotionally from everyone and everything' (p. 142). In becoming separated from other people, Charlie loses his 'centrally firm sense of his own and other people's reality and identity', to repeat Laing's words (1990:39). The dialogic nature of ontological security disturbs his sense of self-identity, of his ability to synthesise '... my looking at me with my view of others' views of me' (Laing 1990:5).

\section{The wounded storyteller}

In his book, The wounded storyteller, Arthur W. Frank (1997) argues that illness constitutes a form of colonisation because the ill person surrenders his or her body to the control of medical authorities. Being admitted into the medical system almost inevitably causes a sense of ontological insecurity for even the most ontologically secure individual, if only temporarily: 'Surrendering one's body to the medical world of "limited liability" is frightening' (Frank 1997:174). Part of this insecurity is reinforced by the individual's obligation to accept his or her subordinate position in the system and in the inequality of the power relationship between doctor and patient.

Frank's ideas of replacing traditional modernist medicine with a post-modernist medicine which places emphasis on the patients' experiences may be traced back to some of the ideological positions and therapeutic experiments (such as Laing's Kingsley Hall) originating in the 1960s, especially those concerning the relationships between doctor and patient and between hospital system and patient. The voice of modernist medicine, according to Frank (1997:5), is univocal. That is to say, it is the authoritative voice of medical experts informing patients. Frank (1997:147) proposes that there is a need for an alternative post-modernist medicine which is multivocal and includes the voice of patients. (Interestingly, Charlie's is the fictional voice of the patient, almost 40 years before Frank's argument for a multi-vocal approach appeared.)

A further consequence of entering the medico-research environment, and losing one's ontologically secure core through medical interventions, is that one is obliged to surrender what one of Frank's correspondents refers to as one's life map and destination (Frank 1997:1). Both of these are matters of time and individuation, of what one plans to become in one's life and how one schedules the time required to achieve it. In hospital, the map and the destination become irrelevant for the immediate or conceivable future, depending on the severity of the illness or the uncertainty of the treatment's or experiment's outcomes. The individual's destination now becomes an issue of alteration, acceptance or even resignation, all of which can exacerbate one's ontological insecurity.

In terms of time, some destinations are no longer attainable. The time now required to complete the life journey as initially planned can no longer be predicted. With the surgery, being 'smart' (p. 8) becomes a serious possibility for Charlie, a new destination requiring a different map for that journey. However, the new map and destination are more likely to be defined by the medical specialists dealing with the patient prior to discharge from the system. It will be up to the patient to adapt to, or reject, the new plans. This adaptation shapes Charlie's future plans once it becomes evident that the experimental outcomes are impermanent.

In The wounded healer, Henri Nouwens (1979:85) explains that the wounded healer often '... finds himself standing on the edges of events and only reluctantly admitted to the spot where the decisions are made'. This closely resembles Charlie's own situation of his being, simultaneously, central as the experimental subject and peripheral as the wounded storyteller in the medico-research system. Whether central or peripheral, Charlie steadily loses his ontological confidence.

Post-operatively, Charlie discovers that he has given up his rudimentary ontological security for the ontological insecurity of an unknown, uncertain future as an evolving intellect. His pre-operative ebullience inhibits his ability to perceive the consequences and implications of what will, or might, happen to him. His understanding is limited to the idea of becoming 'smart'. At that juncture, he cannot grasp that '[i]llness has always threatened the intactness of mind and body' (Frank 1997:172), bringing about the disintegration of the body-self (Frank 1997:173). He does not appreciate that his rapid intellectual growth may not be paralleled by an equally rapid and equally necessary emotional growth. Nor 
does he grasp that an excessively high IQ will render him as societally abnormal, especially when linked to his emotional underdevelopment, as his mildly retarded IQ does.

The interruption of Charlie's sense of being a continuous person is aggravated by the medico-research institution's intrusions into his life. The medical-research system takes over Charlie's life in order to pursue the experiment. Charlie puts his brain and his future time-self into the hands of 'expert' strangers, relying on them for his recuperation (or deterioration). However, as Charlie's intelligence develops, he finds that he can no longer unconditionally accept what is happening to him. He begins to question the medical scientists and the system within which they work. He learns of the extra-academic pressures and politics that Nemur in particular has to bear. Awareness of these contexts allows Charlie to understand (and oppose) the urgency with which Nemur wishes to announce the operation's success. Nonetheless, the hubris in Nemur's premature announcement wounds Charlie ontologically as he grows increasingly aware of the operation's failure on Algernon.

'Medicine's hope of restitution crowds out any other stories' (Frank 1997:83). There are good reasons for this, as Frank (Frank 1997:115) explains later: 'Restitution stories attempt to outdistance mortality by rendering illness transitory'. Indeed, it is this idea of 'cure', of the restitution of Charlie's intellect to 'normal levels', that tempts Nemur into announcing the success of the experiment on both Algernon and Charlie at the Chicago Convention. The significance of Nemur's announcement is that it occurs in early June. At that time, Charlie's experiment has been running for only a little over three months; long-term outcomes have yet to be envisaged. In Algernon's case, his decline begins after the conference.

Frank (1997) makes the following argument:

The body of the restitution story is fundamentally monadic in its relation to other bodies. The disease model of medicine reinforces this conception of each patient 'having' a disease, and this disease model articulates well with modernist emphases on the individual as an autonomous entity. The same conception of the individual that makes it sensible to speak of 'having' a disease can speak of 'having' rights, 'getting' an education, or ... 'having' empathy. Diseases, rights, education, and empathy are seen as properties of specific persons, not as expressions of persons' relationships with others. (p. 85)

This sense of the specificity of one's illness serves to isolate individuals within that illness, differentiating them from other, and so adding to their feelings of ontological insecurity.

Not surprisingly, as Frank (1997:172) notes: ‘[ $p$ ]eople are also threatened by institutions ostensibly designed to help them'. He continues: ' $[t]$ he sick role is no longer understood as a release from normal obligations; instead it becomes a vulnerability to extended institutional colonization' (Frank 1997:172). The patient is required to acquiesce to the demands of the hospital's regimen in the name of healing and restitution.
The sense of threat evident in Charlie's experiences during the experiment comes early on from his inferior, disempowered position in the system and from his early inability to exercise any sort of control over the processes to which the system submits him. However, as Charlie's awareness develops (and his ontological security diminishes), he states in Progress Report 13: '[I]t's frightening to realize that my fate is in the hands of men who are not the giants I once thought them to be, men who don't know all the answers' (p. 108). Frank (1997) explains this as follows:

The restitution is brought about by an agency outside the body: medicine operating through either surgery or drugs. The body's own contingency is remedied, but only by dependence on an agency that is other to the body. (p. 85)

It is apparent from this situation of dependence on external agencies for the restitution of the body's condition that such dependence compounds the patient's feelings of ontological insecurity. One should recall here Laing's idea that an individual's ontological security is dialogic and depends on others' perceptions. This process takes place within the context of the unequal power relationship between the patient's medical ignorance and the medical expertise of the doctors. A further aggravation is that '... often physicians are understood as fronting a bureaucratic administrative system that colonizes the body by making it into its "case"' (Frank 1997:172).

The consequences of illness (especially mental illness) and restitution carry social issues with them, including stigmatisation and matters of acceptance. If a person's medical shortcomings can be, and are, corrected, then, Goffman (1990) is correct in noting the following:

(Where such repair is possible, what often results is not the acquisition of fully normal status, but a transformation of self from one with a particular blemish into someone with a record of having corrected a particular blemish.) (p. 19-20; parentheses original)

Had Charlie's operation proven a long-term success, he would have been perceived by others as being a mentallyretarded individual who had undergone rectifying surgery, but he would not have been seen as having been restored to wholeness or normality. He would still bear the stigma of abnormality, if only by virtue of having undergone the operation itself.

Once Charlie's intelligence has achieved supernormal levels, well beyond that of the researchers conducting the experiment, he is allowed to conduct his own research into its likely outcomes, outcomes epitomised by Algernon's progress. Thus, Charlie ceases to be a subordinate in the system, acquiring a certain measure of control over the experiment. However, that autonomy does not bring ontological security with it but just the opposite.

Implicit in Frank's term, 'colonisation', is the idea that patients may be obliged to accept the possibility of spending some time 
in hospital, in what Goffman terms (1984:16) a total institution. His 'five rough groupings' of total institutions (Goffman 1984:16) range from homes for the aged, army camps, ships and boarding schools to retreat centres, monasteries and several others. Goffman's second grouping is pertinent here. This consists of 'places established to care for persons felt to be both incapable of looking after themselves and a threat to the community, albeit an unintended one: TB sanitaria, mental hospitals, and leprosaria' (Goffman 1984:16). We cannot miss the implications of sandwiching mental illness between two highly infectious and socially stigmatised diseases, both requiring the patients' separation or isolation from the community. This symbolic position of mental illness reflects the concerns of the 1960s anti-psychiatry lobby about the presumptions inherent in the ways society and traditional medicine perceive mental illness and how its sufferers are to be hidden away from normal society.

\section{The question of time}

As we have seen earlier, Laing (1990:39) argues that the ontologically secure individual experiences himself or herself as 'a continuous person' in terms of time. He or she can then understand the 'world and others' as equally 'continuous'. Ontological insecurity, in contrast, is jeopardised by interruptions to that sense of continuity, and as Frank has noted previously, any form of illness begins with a disruption of that continuity.

In The divided self, Laing (1990:108) also discusses the role that self-consciousness plays in the 'ontologically insecure person'. In particular, he refers to temporality:

... sometimes the greatest reliance may be placed on the awareness of oneself in time. This is especially so when time is experienced as a succession of moments. The loss of a section of the linear temporal series of moments through inattention to one's timeself may be felt as a catastrophe. (Lang 1990:109; italics added)

Charlie becomes ever more aware that the uncertainty inherent in the experiment's progress towards success or failure undermines the possibility of the time-self functioning within a continuous narrative. Consequently, the question of time assumes increasing significance in his life. The medicoscientific interruptions, each with its unpredictable outcomes of progress or regression, oblige Charlie to function within a timeframe perceived as 'a succession of moments' (Laing 1990:108) devoid of continuity.

With the ever-mounting evidence of the experiment's failure and the escalating urgency Charlie feels as a consequence of his intellectual decline, time (or the lack of it) presents an ever-more powerful threat to his precarious ontological state. The pressure to complete his research report is aggravated by the unpredictability of the amount of time remaining and by what happens to Algernon, who serves as the experiment's augury of Charlie's own fate. Charlie's ontological insecurity is directly linked to the passage of time through recurrent questions such as 'How long before ...?', 'How much time remains ...?' and the like.
Once Charlie has entered the medico-research system, everything that happens to him - his intellectual growth and subsequent decline, his increasing ontological insecurity, the increasing tempo of his regression - become matters of time. The medico-research environment itself compounds the individual's insecurity. Patients are obliged to question whether they are truly 'whole' in the Laingian sense. This leads the patients to wondering not only whether they can ever be 'real' and fully 'alive' within the system but also how long they will remain ontologically insecure in the face of illness and the restitution procedures. Goffman (1990:49) contends that '.. the medical profession is likely to have a special job of informing the infirm who he [or she] is going to have to be'. Quite explicitly, Goffman presumes that patients will be altered by what happens to them although they have little choice in the matter. Their new maps and their new destinations will not be matters of their own volition but will be presented to them by doctors and/or specialists. These new maps and destinations will, implicitly or explicitly, function within the constraints of time. Charlie's case is no exception.

The patient's ontological insecurity is likely to be expressed in terms of questions about time: How long will the healing process take? Am I going to die? If so, when will it happen? How long will it take? The generic answer to such questions is: It's a matter of time, of waiting for the outcomes, whether positive or negative. However, the resilience demanded by the waiting itself may be debilitating. The continuity of a person and his or her sense of ontological security rely on a 'temporal sense' devoid of interruption. (One of the synonyms for 'disruption' is disorder). Yet, the medical environment disrupts the ordered life so that it becomes disjointed and unpredictable.

Charlie is flown to Chicago to be put on display with Algernon as experimental specimens at the convention:

No one in this room considered me an individual - a human being. The constant juxtaposition of 'Algernon and Charlie' and 'Charlie and Algernon' made it clear that they thought of both of us as a couple of experimental animals who had no existence outside the laboratory. (p. 113)

Charlie's anger at being perceived and demeaned in this manner is reinforced when Nemur offers his scientist's perspective on Charlie's development:

When Charlie came to us he was outside of society, alone in a great city without friends or relatives to care for him, without the mental equipment to live a normal life. No past, no contact with the present, no hope for the future. It might be said that Charlie Gordon did not really exist before this experiment... (p. 113)

The crass hubris in Nemur's public assessment of Charlie wounds him ontologically at precisely the moment that his extraordinary intellectual development is being announced.

Nemur's is a rather melodramatic version of Charlie's preoperative life. For example, he asserts that Charlie 'came to us' whilst the reality is that the scientists sought Charlie out as an experimental subject. He is not without relatives: 
His mother had placed him in the Warren Home whilst his sister, Norma, who thought Charlie was dead (p. 117), gives permission for the operation. Charlie certainly has a past, albeit a deeply troubled one, especially in his relationship with his violent mother, Rose. His work at Donner's Bakery is a source of his own rudimentary ontological security as we have seen. Nemur's picture of Charlie prior to the experiment is clearly intended to reveal the scientist's professional self-aggrandisement, the hubris that deceives him into the premature declaration of the operation's success.

Subsequently, after the Beekman research group has returned from the conference and in an effort to regain a modicum of ontological security, Charlie tackles Nemur at the cocktail party that his wife has organised '... in honor of the two men on the board of the Welberg Foundation who had been instrumental in getting her husband the grant' (p. 170).

In this altercation, Charlie says:

The problem, dear professor, is that you wanted someone who could be made intelligent but still be kept in a cage and displayed when necessary to reap the honors you seek. The problem is that I'm a person. (p. 174)

In response to Nemur's assertion that they had 'done everything we could for you', Charlie points out that:

... what you did for me - wonderful as it is - doesn't give you the right to treat me like an experimental animal. I'm an individual now, and so was Charlie before he ever walked into that lab. You look shocked! Yes! Suddenly we discover that I was always a person - even before - and that challenges your belief that someone with an IQ of less than 100 doesn't deserve consideration. Professor Nemur, I think that when you look at me your conscience bothers you. (p. 174)

Charlie's outburst has its origins partly in his increasing uncertainty about his future, especially in the light of Algernon's recent behaviour, and partly in his inability to understand Nemur's own ontological issues, even though Burt, the PhD candidate, has already explained Nemur's personal situation to Charlie:

If you want to understand why he's under tension all the time, even when things are going well at the lab and in his lectures, you've got to know Bertha Nemur. Did you know she's got him his professorship? Did you know she used her father's influence to get him the Welberg Foundation grant? Well, now she's pushed him into this premature presentation at the convention. Until you've had a woman like her riding you, don't think you can understand the man who has. (p. 107)

Bertha Nemur fails to see the professional, personal and social dangers of her husband's premature announcement of success, let alone its impact on Charlie.

The Chicago Convention takes place in early June, just a few months after Charlie's surgery. About a month after the conference, on 09 July, Algernon bites Fay. Three days after that, Burt tells Charlie about Algernon: 'He's forgotten a lot. Most of his complex responses seem to have been wiped out.
He's solving problems on a much more primitive level than I would have expected' (p. 152). Almost a fortnight later, on 27 July, Charlie observes that Algernon's regression has worsened considerably: 'Algernon lies in his dirt, unmoving, and the odors are stronger than ever before. And what about me?' (p. 168). Charlie reformulates the question later: 'Now what becomes of me?' (p. 178). Charlie's fate will always be presaged by what happens to Algernon.

Hoping that he will have as much time as he needs to complete his research constitutes Charlie's sustaining delusion of the operation's success, a delusion that would affirm the validity of the restitution narrative. However, any sense of wholeness, of continuity, of having a map that can be followed to a predictable destination is constantly disrupted by events in Algernon's life and what they forebode in Charlie's. The idea of the re-integration of the body-mind self, of achieving integrity, is undercut by negative realisations: 'I may not have all the time I thought I had' (p. 116).

When the delusions of ontological security fail him, Charlie is compelled to be brutally realistic about his future:

That's the problem, of course. I don't know how much time I have. A month? A year? The rest of my life? That depends on what I find out about the psychophysical side-effects of the experiment. (p. 148)

The phrase, 'The rest of my life', is notably ambiguous. Behind it lies the presumption that the operation's regressive phase will not take Charlie all the way back to his pre-operative mental state. And his reference to 'the psychophysical side' recalls Laing's mention of the biological aspects of ontological (in)security, quoted earlier.

In his report for 8 July, Charlie observes that Algernon's behaviour is 'becoming erratic again' (p. 150). The passing of time reveals the impermanence of the experiment's outcomes. Charlie's telling use of the word 'again' cannot be overlooked. The following day, the mouse's behaviour takes on an aggressive dimension as well:

July 9 - A terrible thing happened today. Algernon bit Fay ... He bit her thumb. Then he glared at both of us and scurried back into the maze ... I observed him for more than an hour afterward. He seems listless and confused, and though he still learns new problems without external rewards, his performance is peculiar. There is a strange sense of urgency in his behaviour. (p. 150-151)

Algernon's urgency, his 'scurry', becomes Charlie's own, its presence manifest in his reports as recurrent questions about time. Shortly after this episode, Charlie notes (p. 153): 'Time was the barrier. If I was going to find out the answers for myself I had to get to work immediately.' Henceforth, there would be 'a strange urgency' (p. 151) in Charlie's behaviour, too.

The purpose of Charlie's investigation, as he explains, centres on the following:

... finding out who I really am - the meaning of my total existence involves knowing the possibilities of my future as 
well as my past, where I'm going as well where I've been. (p. 155)

The idea of comprehending the way in which the past and the future relate to his understanding of 'the meaning of my total existence' suggests an attempt to overcome the ontological insecurity of being a discontinuous person so that 'a world and others [are] experienced as equally real, alive, whole, and continuous', as Laing (1990:39) describes them. In so doing, he would re-establish 'a centrally firm sense of his own and other people's reality and identity', including those of his parents, his sister and his co-workers. Of course, 'knowing the possibilities of my future as well as my past, where I'm going as well as where I've been' (p. 155) would also require Charlie to find, in Frank's terms, a new destination and a new map by which to get there.

However, witnessing Algernon's steady deterioration, Charlie knows he is witnessing his own future. If he is to give some sense of cohesion to all his research findings before he himself reverts to his status quo ante, he realises: 'I've got to cram a lifetime of research into a few weeks. I know I should rest, but I can't until I know the truth about what is happening' (p. 167). He hopes to allay his fears about the uncertainty of what awaits him by striving for the truth, something he cannot prise out of the researchers. At the same time, he is aware of the pressure of time and the ontological uncertainty that accompanies it: 'Time assumes another dimension now - work and absorption in the search for an answer' (p. 166). The work he must accomplish serves as a provisional buffer, providing a token of security in, or a provisional distraction from, his insecure world.

Whilst he is regressing, and knowing he may well regress to a level lower than before the operation, Charlie learns of the laboratory's plans for his future, that he is destined to live out the rest of his days at the Warren State Home and Training School (p. 154), an institution housing brain-damaged individuals that ' $[t]$ he world doesn't want' (p. 157). He was committed there as a youth by his mother and has worked at Donner's Bakery 'on outside work placmint' (p. 17) for the last 17 years. At that time, Mr Donner assured Charlie that he has 'a job here for the rest of your life ... You'll never have to go back to that Warren home' (p. 17). However, Mr Donner cannot protect Charlie from the Welberg Foundation's plans. After learning what his final destination is, he visits the place two days later because 'I've got to know what's going to happen while I'm still enough in control to be able to do something about it' (p. 155). Charlie needs to confront the idea of his being colonised in another total institution, one that will isolate him from normal society permanently because the world does not want him - or, at least, does not know what to do with individuals like him other than to keep them separate because they are 'persons felt to be both incapable of looking after themselves and a threat to the community, albeit an unintended one', to reiterate Goffman's words (1984:16).

Although time remains the driving force behind his efforts, he also worries about his imminent mental state: 'The only question now is: How much can I hang on to?' (p. 180). Thus, the passage of time and his intellectual deterioration combine to produce a further escalation of his ontological insecurity. His research has been pared down to the essentials:

There isn't time. The work is done, the data is in, and all that remains is to see whether I have accurately projected the curve on the Algernon figures as a prediction of what will happen to me. (p. 180)

Charlie submits his report and a covering letter to Nemur and Strauss on 26 August. On 17 September, Charlie notes that Algernon 'died two days' ago:

Dissection shows that my predictions were right. Compared to the normal brain, Algernon's had decreased in weight and there was a general smoothing out of the cerebral convolutions as well as a deepening and broadening of brain fissures. (p. 181)

Charlie recognises the threat to his ontological state of mind: '[i]t's frightening to think the same might be happening to me right now' (p. 181). Desperate hope is still present in Charlie's use of the word, 'might'. The reality is that, if it is not happening 'right now', it certainly will be shortly.

With his research completed, Charlie has to acknowledge harsh reality: 'There's nothing to look forward to. I don't dare let myself think ahead - only back. In a few months, week, days - who the hell knows? - I'll go back to Warren' (p. 205). The irony in this last statement is that Charlie has visited Warren just recently as the super-intelligent exemplar of the operation's success. He is fully aware, too, that whatever plans he might have had for the future - the map and destination of Frank's wounded storyteller - have rapidly become redundant in the face of his ongoing retardation.

Charlie's ontological insecurity culminates in early October when he writes: 'Downhill. Thoughts of suicide to stop it all now while I am still in control and aware of the world around me' (p. 195). However, he decides against that option, consoled by knowing that ' $t[$ hese progress reports are Charlie Gordon's contribution to mankind' (p. 195).

Charlie escapes from his fears into the mind-numbing mediocrity and tedium of television, 'watching the quiz programs, the old movies, the soap operas, and even the kiddie shows and cartoons. And then I can't bring myself to turn it off' (pp. 208-209) and realising, as he does, that 'I'm sick with myself because there is so little time left for me to read and write and think' (p. 209). He would seem to be emulating Algernon's lethargy, pre-mortem.

And yet, when he does overcome that lethargy, when he tries to re-read an article he had used in his research, he discovers: 'I could no longer read German' (p. 209). Testing himself in 'other languages', he discovers they too are ' $[a] l l$ gone' (p. 209). Charlie, the polyglot scientist, who was perturbed that Professor Nemur could not 'read Hindi or Japanese' (p. 105), and the classical composer - 'I dedicated my first piano concerto to Fay' (p. 149) - of three months earlier now 
watches television even when the station closes down and 'the channel test pattern .... stares back ... with its unclosing eye' (p. 209). Time is running away from him: 'November $1-$ A week since I dared to write again. I don't know where the time goes' (p. 212).

Unlike his pre-operative retarded condition, Charlie is now fully conscious of his relapse. However, the failure of the operation would no longer be a source of laughter and taunting by his former workmates at the bakery when he visits them:

I said to myself Charlie if they make fun of you dont get sore because you remember their not so smart like you once thot they were. And besides they were once your frends and if they laffed at you that don't mean anything because they liked you to. (pp. 215-216)

Charlie does not return to Donner's Bakery. He returns to the Warren Home instead because of the following reason:

I don't want Miss Kinnian to feel sorry for me. I know everybody feels sorry for me at the bakery and I don't want that eather so Im going someplace where they are a lot of pepul like me and nobody cares that Charlie Gordon was once a genus and now he cant even reed or rite good (p. 217)

His regression has come full circle when he admits: 'Its easy to have frends if you let pepul laff at you. Im going to have lots of frends where I go' (p. 218). Charlie's initial ontological security has also come almost full circle, having returned after passing through various phases of ontological threat and insecurity in the months after the operation.

At the same time, Charlie acknowledges that the experiment has not been entirely futile. In his last report, he writes:

Im glad I got a second chanse in life like you [Miss Kinnian] said to be smart because I lerned alot of things that I never even new were in this world and Im grateful I saw it all even for a littel bit. And Im glad I found out all about my family and me. It was like I never had a family til remembird about them and saw them and now I know I had a family and I was a person just like evryone. (p. 217-218)

Charlie is almost ontologically secure once more, albeit in his rudimentary way. However, just in case he can 'practise hard' and 'get a littel bit smarter then I was before the operashun', he takes some tangible assurance with him: 'Im taking a cuple of books along ... I got a new rabits foot and a luky penny and even a littel bit of that majic powder left and maybe they will help me' (p. 218). Ontological security may take many forms.

\section{Conclusion}

In differentiating the illness story from most other stories, Frank (1997) draws attention to the customary assumptions of both listeners and storytellers:

The conventional expectation of any narrative, held alike by listeners and storytellers, is for a past that leads into a present that sets in place a foreseeable future. The illness story is wrecked because its present is not what the past was supposed to lead up to, and the future is scarcely thinkable. (p. 55)

Assuming Frank is correct about the conventional expectation of narratives, then Charlie's is an illness story that is also wrecked, and for the reasons Frank explains.

Although Charlie's is an account of how an apparently benevolent intrusion into his life seems to offer a better life or, at least, a normal life, he has no idea where the experiment might lead nor any initial sense of what ontological security he will have to surrender as a consequence. At the outset, only the scientists are aware of the possibilities that the surgery may not provide the map leading to the desired destination. They remain unaware of, or insensitive to, the ontological insecurity that the experiment brings into Charlie's life. Amid the eventual wreckage of his life, he seeks to salvage some small pieces of his intelligence, despite the mounting pressures of time and his deteriorating intelligence.

Flowers for Algernon is not a restitution story either. It is an account of medical science's failure to achieve restitution. The opportunity to escape a mildly-retarded mental condition and become 'smart', (that is, normal by society's conventional measures), seems irresistible, containing, as it does, considerable promise and the fulfilment to which one might expect that promise to lead. However, such expectations do not feature on Charlie's post-operative map. Charlie's new map steers him towards a different destination as he returns to the total institution of Warren State Home where those for whom the normal world has no other place are housed.

In Warren, Charlie forgets most of the ontological insecurity that the experiment brought into his life whilst still clinging to his initial desire: 'I wish I could be smart again rite now' (p. 218). Although he takes solace in what little he can recall of being 'the frist dumb persen in the world who found out some thing importent for sience' (p. 218), he cannot fathom why the experiment failed: 'I dont no why Im dumb again or what I did rong. Mabye its because I dint try hard enuf or just some body put the evel eye on me' (p. 218). Henceforth, Charlie's initial, rudimentary ontological security will always be tainted by a modicum of the ontological insecurity that the operation brought into his life.

\section{Acknowledgements Competing interests}

The author declares that he has no financial or personal relationships which may have inappropriately influenced him in writing this article.

\section{References}

Bentall, R.P., 2004, Madness explained: Psychosis and human nature, Penguin, Harmonsworth.

Bohm, D., 2004, On creativity, Routledge, Abingdon \& New York.

Cooper, D., 1967, Psychiatry and anti-psychiatry, Tavistock Publications, London.

Cooper, D., 1971, The death of the family, Vintage, New York. 
Frank, A.W., 1997, The wounded storyteller: Body, illness, and ethics, University of Chicago Press, Chicago. http://dx.doi.org/10.7208/chicago/9780226067360.001.0001

Goffman, E., 1984, Asylums, Penguin, Harmondsworth.

Goffman, E., 1990, Stigma: Notes on the management of spoiled identity, Penguin London.

Hook, D., 2002, 'Introduction: A "social psychology" of psychpathology', in D. Hook \& G. Eagle (eds.), Psychopathology and social prejudice, pp. 2-18, University of Cape Town Press, Cape Town. http://dx.doi.org/10.1177/008124630203200204

Keyes, D., 1989, Flowers for Algernon, London: Heinemann.

Laing, R.D., 1970, Sanity, madness and the family, Penguin, London.

Laing, R.D., 1990, The divided self, Penguin, London.
Laing, R.D., Phillipson, H.J. \& Lee, A.R., 1966, Interpersonal perception, Tavistock Publications, London.

Long, C. \& Zietkiewicz, E., 2002, 'Unsettling meanings of madness: Competing constructions of South African insanity', in D. Hook \& G. Eagle (eds.), Psychopathology and social prejudice, pp. 152-168, University of Cape Town Press, Cape Town.

Nouwens, H.J.M., 1979, The wounded healer, Image Books/Doubleday, New York.

Sedgwick, P., 1982, Psycho politics: Laing, Foucault, Goffman, Szasz and the future of mass psychiatry, Harper \& Row, New York.

Watts, A., 1997, 'Introduction', in M. Watts (ed.), The culture of counter-culture, pp. vii-xi, Tuttle Publishing, Boston. http://dx.doi.org/10.2307/3269224 